\title{
微動H/Vと重力探査による 福井平野の地下構造推定
}

\author{
安井譲 $1 \cdot$ 野口竜也 $2 \cdot$ 橋本勇一 $3 \cdot$ 中谷英史 $4 \cdot$ 香川敬生 5 \\ 1福井工業大学工学部土木環境工学科 教授（广910-8505福井市学園3-6-1） \\ E-mail:yasui@fukui-ut.ac.jp \\ 2 鳥取大学大学院工学研究科 社会基盤工学専攻 助教（广680-8552鳥取市湖山町南4-101） \\ E-mail:noguchit@cv.tottori-u.ac.jp \\ 3 福井工業大学大学院工学研究科 建設工学専攻 大学院生（T910-8505福井市学園3-6-1） \\ E-mail:mc2102yh@fukui-ut.ac.jp \\ 4 鳥取大学大学院工学研究科 社会基盤工学専攻大学院生（广680-8552鳥取市湖山町南4-101） \\ E-mail:nakaya05044@cv.tottori-u.ac.jp \\ 5 鳥取大学大学院工学研究科 社会基盤工学専攻 教授（干680-8552鳥取市湖山町南4-101） \\ E-mail:kagawa@cv.tottori-u.ac.jp
}

\begin{abstract}
福井平野で既に行われている微動アレイ観測に基づく地盤速度構造を照査・検討することを目的として 福井平野西縁部の4つのアレイ観測点を通る南北の測線において詳細な微動 $\mathrm{H} / \mathrm{V}$ 観測と重力観測を行った. 重力観測は基盤が露頭していると考えられる東西の山地についても実施した。また, 微動 $\mathrm{H} / \mathrm{V}$ 探査では

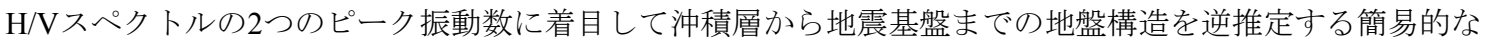
方法を提案している．微動H/Vスペクトルと重力観測から推定した新第三紀層や地震基盤の深さはアレイ 観測の結果と一部不整合な部分が見受けられるものの，その大まかな形状は一致した.
\end{abstract}

Key Words : Fukui Plain, microtremor, H/V spectrum, Rayleigh wave, soil velocity structure, genetic algorithm, gravity survey, mass density, tertiary layer, seismic bedrock

\section{1.はじめに}

著者らは福井平野の深層地盤速度構造を明らかに することを目的として，福井平野とその境界部の6 測点において微動アレイ観測を行ってきた1).これ らの速度構造を2次元あるいは3次元的なデータで照 查・検討することを考えて, 福井平野西縁部の $4 つ$ の微動アレイ観測点に沿う南北の測線において詳細 な微動 $\mathrm{H} / \mathrm{V}$ 探査と重力探查を行なった。ここに，微 動H/V探査ではH/Vスペクトル2)の2つのピーク振動 数 ${ }^{3)}$ に着目して沖積層から地震基盤までの地盤構造 を逆推定する簡易的な方法を提案している. なお, 重力探査では既存の探査例4)で基盤の傾斜が急峻と されている東西の山地および平野境界部についても 測点を設けて観測を実施した.

\section{2. 微動H/V探査}

\section{（1）観測の概要}

微動3成分観測は微動アレイ観測点を通る福井平 野西縁部の南北の約 $20 \mathrm{~km}$ の測線で 2008 年の 10 月 24
日〜26日，11月8日と 12 月 12 日に実施した。図-1に 微動3成分観測点の位置を示したが，これらの測点 の間隔は $500 \mathrm{~m}$ である。なお, 微動アレイ観測は, 本測線上の菅谷(No.4の近傍), 山室(同No.15), 春江 (同No.20), 東荒井(同No.29)の4地点に, 板垣と丸岡 を加えた6地点で行われている1).

微動 3 成分観測の概要は以下のようである. 即ち, 地震計はアカシ製のGPL-6A3Pで, 測定時間は20分, サンプリング周波数は $100 \mathrm{~Hz}$ ，またローパスフィル ターの折点周波数は $5 \mathrm{~Hz}$ とした。 得られたデータか ら雑音のない良好な区間（20.48秒）を10組選定し て，その後半部に20.48秒の0区間を付加してスペク トル計算を行ない，H/Vスペクトルを求めた。なお， 0区間を付加したのは計算振動数幅を小さくして低 振動数域の分解能を上げるためで，付加しない場合 と比べてH/Vスペクトルの形状やピーク振動数に有 意な差がないことを確認している.

\section{（2）微動H/Vスペクトル}

図-2に微動H/Vスペクトルの例としてNo.4測点の ものを示した．同図と後述する図-3に見られるごと く, 岩盤が露頭していると考えられる南北両端の数 


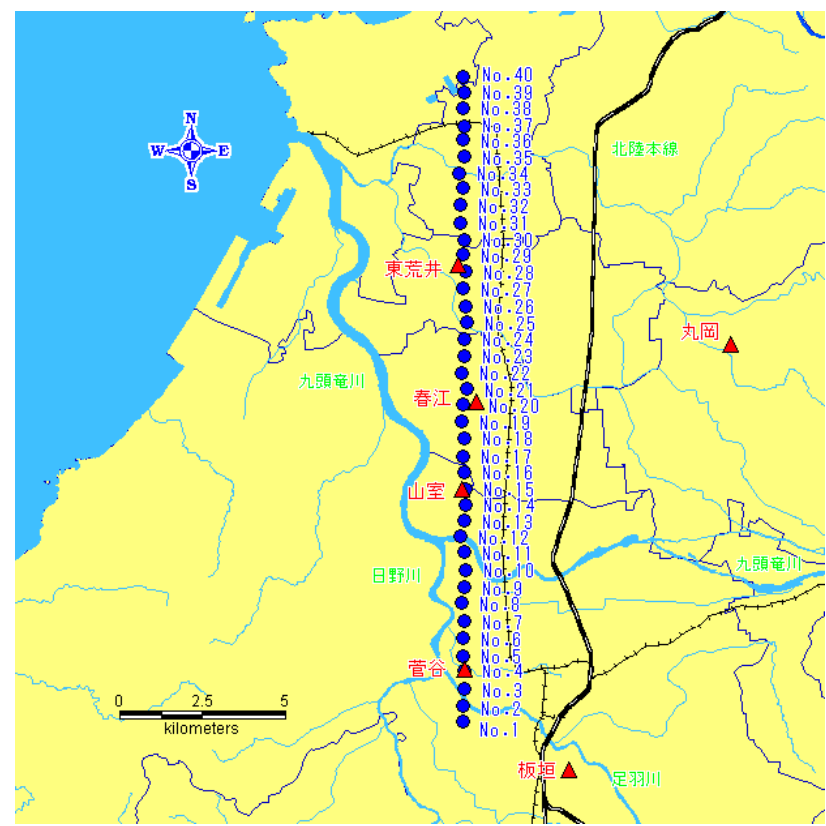

図-1 微動3成分観測点

とアレイ観測点 $(\boldsymbol{\Delta}$

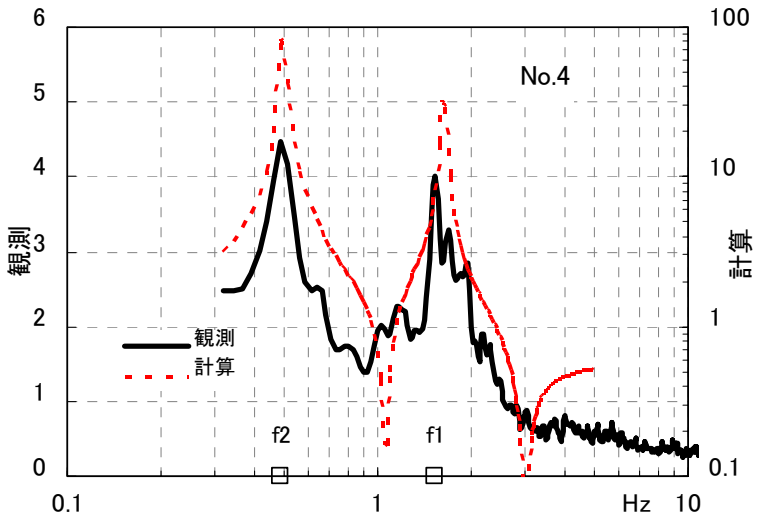

図-2 微動H/Vスペクトルの例（No.4測点）

地点を除き，2つのピークを有する複峰型のスペク トル形状を示した。ここに, Parzenウィンドウの幅 は $0.1 \mathrm{~Hz}$ である. 同図では, $1.54 \mathrm{~Hz}\left(f_{1}\right)$ と $0.49 \mathrm{~Hz}\left(f_{2}\right)$ にピークが認められる. 図-3に $f_{1}$ と $f_{2}$ に対応寸る 周期 $T_{1}\left(=1 / f_{1}\right)$ と $T_{2}\left(=1 / f_{2}\right)$ の分布を示した.

\section{（3）地盤構造の推定}

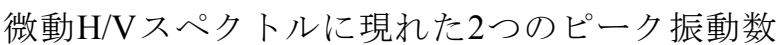
を利用して地盤構造を推定するが，その手順は以下 のようである。

まず，図-4に示すように地盤構造を単純化して, 沖積層, 洪積層, 新第三紀層および地震基盤からな る4層構造を仮定する。沖積層と洪積層の $\mathrm{S}$ 波速度 $V_{S 1}$ と $V_{S 2}$ はアレイ観測結果 ${ }^{1}$ を参考にして，それぞ れ $170 \mathrm{~m} / \mathrm{s}, 580 \mathrm{~m} / \mathrm{s}$ とした。新第三紀層と地震基盤 のS波速度 $V_{S 3}$ と $V_{S 4}$ は既往の研究占に倣い，それぞ

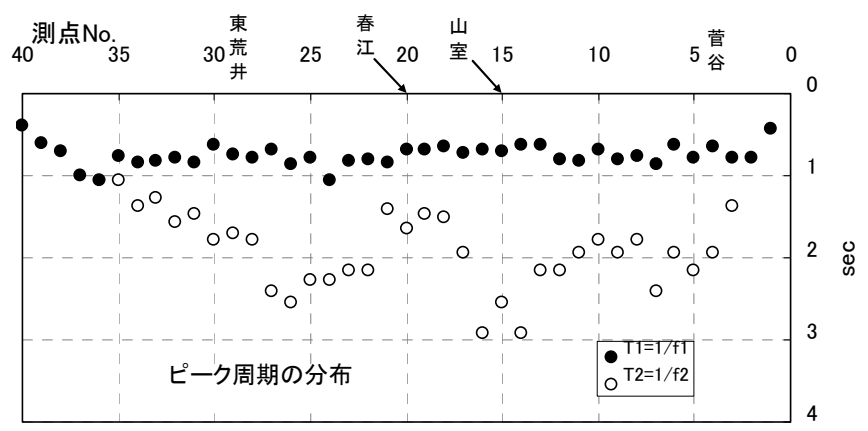

図-3 微動H/Vスペクトルのピーク周期の分布

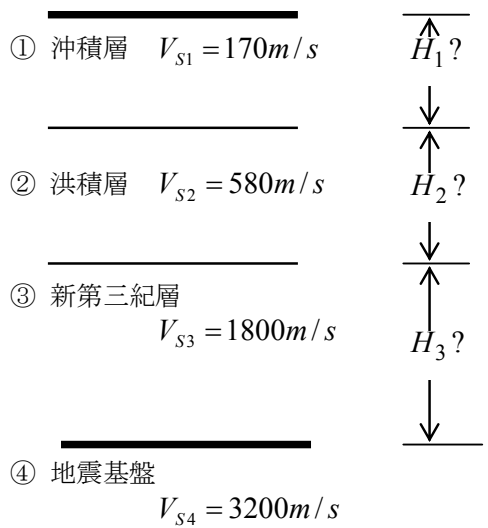

図-4 単純化した地盤モデル

れ $1,800 \mathrm{~m} / \mathrm{s}$ と 3,200 m/s とした。また，第(1)層〜 (4)層 の地盤密度も同研究を参考にして，それぞれ1.7, 1.8, 2.0 おび $2.5 \mathrm{~g} / \mathrm{cm}^{3}$ とし，P波速度はS波速度との関係 を表す狐崎らの経験公式のにより定めた.

沖積層の厚さ $H_{1}$ は $1 / 4$ 波長則に基づく式(1)により 求める. 洪積層の厚さ $H_{2}$ と新第三紀層厚 $H_{3}$ は, レ イリー波の基本モード7)の水平/上下振幅比スペクト ルのピーク振動数が観測による $f_{2}$ に一致するよう にGA探索8),9)で求めるが，その探索は $f_{2}$ のピーク周 辺の限られた範囲で行うものとし, $H_{2}$ の探索目標 の目安 $H_{2}{ }^{\prime}$ は $1 / 4$ 波長則に基づく式(2)により定めた。 式(3)にGA探索の評価関数を示した。こうして定ま った地盤モデルの計算值の $f_{1}$ のピーク振動数の近 似度が思わしくない場合は観測值に適合する方向に $H_{1}$ の值を微調整して再度 $H_{2}$ と $H_{3}$ の最適値を探索 するものとする. ここに, $N$ : 振動数 $f_{i}$ の数, $R_{0}: \mathrm{H} / \mathrm{V}$ の観測值, $R_{c}$ : 同計算値, 等々である.

$$
\begin{gathered}
f_{1}=\frac{V_{S 1}}{4 H_{1}} \\
f_{2}=\frac{V_{S 1} H_{1}+V_{S 2} H_{2}^{\prime}}{4\left(H_{1}+H_{2}^{\prime}\right)^{2}}
\end{gathered}
$$



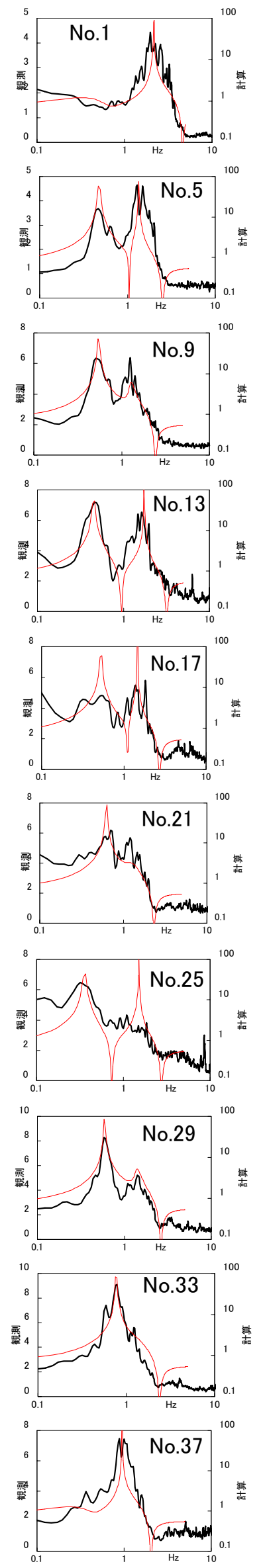
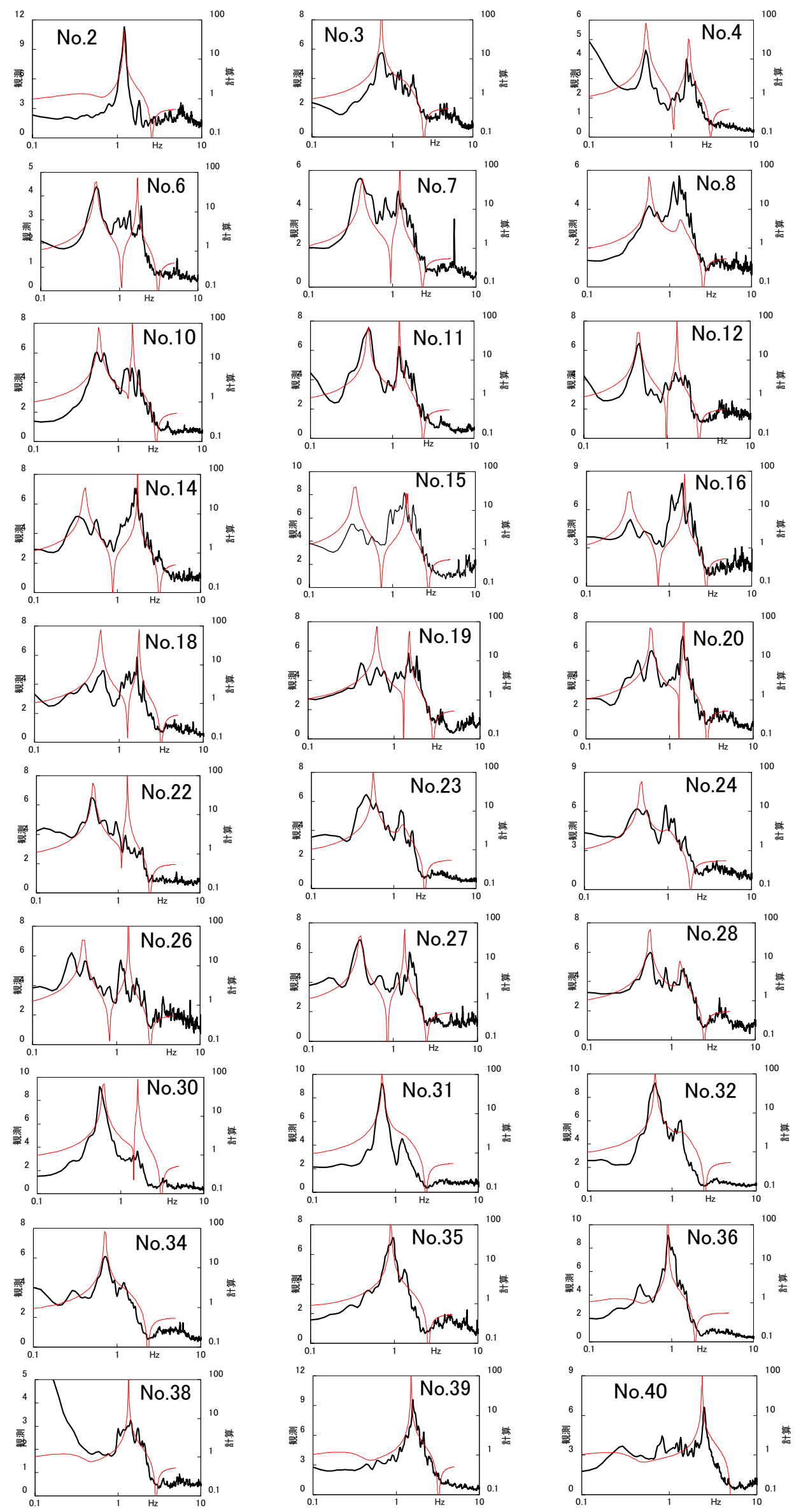

一 観測（左軸）

図-5 微動 $\mathrm{H} / \mathrm{V}$ スペクトルの観測值と計算值の比較 


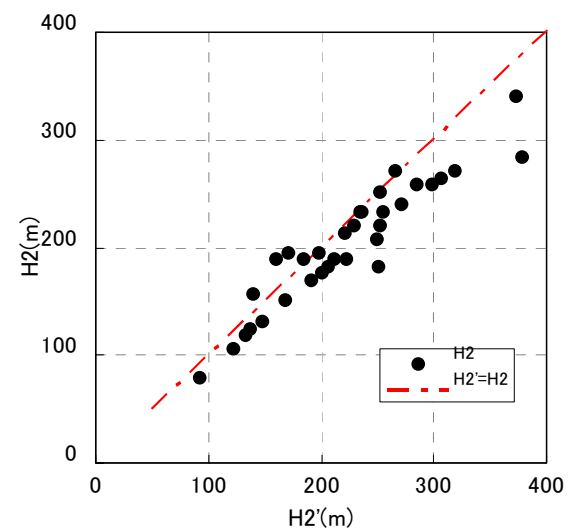

図-6 $\mathrm{H}_{2}$ と $\mathrm{H}_{2}{ }^{\prime}$ との関係

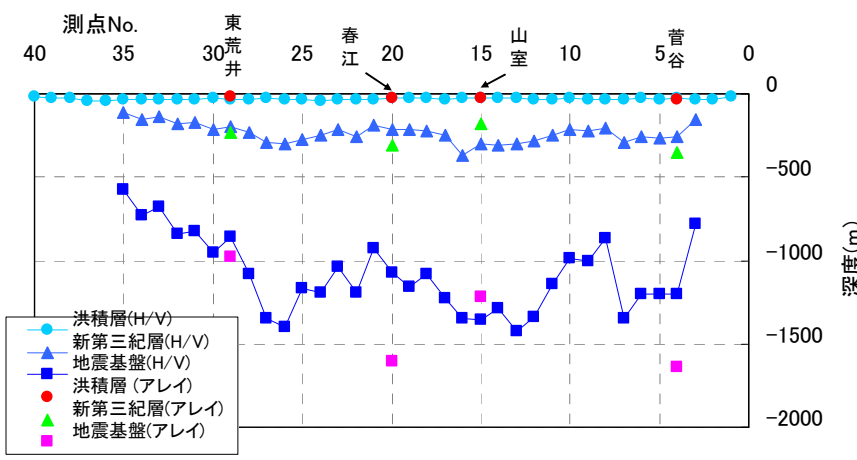

図-7 微動 $\mathrm{H} / \mathrm{V}$ と微動アレイ観測から推定した地盤構造

$$
E=\frac{1}{N} \sum_{i=1}^{N}\left[R_{0}\left(f_{i}\right)-\alpha \times \log \left\{R_{c}\left(f_{i}\right)\right\}\right]^{2}
$$

ここに， $\alpha$ は観測值を計算值の対数值と近似させ るための調整係数で次式を目安に定めるものとする.

$$
\alpha \approx \max \left[R_{0}\left(f_{i}\right)\right] / \log 100=\max \left[R_{0}\left(f_{i}\right)\right] / 2
$$

本方法は，調整係数を導入してH/Vスペクトルの 振幅值の最適化を緩和するなど, より厳密な手法 10),11)を簡略化したものであるが，2つのピークを実 体波の増幅特性で関連づけようとする他の近似的な 方法3),12)に比べると地震基盤の深さまで推定できる ところにその特色がある。

探索計算では，個体数を 30 , ビット数を 6 , 世代 数を 100 とし, 交叉確率を 0.7 , 突然変異確率を 0.01 とし，グレイコード，動的突然変異およびエリート 選択を考慮した. $\mathrm{H}_{2}$ の探索範囲は $0.5 \mathrm{H}_{2}{ }^{\prime} \sim 1.5 \mathrm{H}_{2}{ }^{\prime}$ と し， $H_{3}$ の探索範囲は100～3,000mとした。 また， $\alpha$ は2.5〜 5の範囲の值となり， $N$ は10点前後である. なお，予備解析において 3 回の試行を行ったが変動 率は無視しうるほど小さかったので本解析における
試行回数は1回としている.

図-2にはH/Vスペクトルの同定結果の例を示して ある。同図で計算とあるのは同定した地盤定数を用 いて計算したレイリー波の基本モードの水平/上下 振幅比である。図-5に全測点の微動H/Vスペクトル の観測值と計算值を比較したものを示したが，殆ど の測点で両者はよく一致している。なお，これら の図では, ピーク振動数が合致しているかどうかを わかりやすく示すため, 観測值を線形軸で計算值を 対数軸で示してある.

図一6に $\mathrm{H}_{2}$ と $\mathrm{H}_{2}{ }^{\prime}$ との関係を示しておいた。同図 において $\mathrm{H}_{2}$ と $\mathrm{H}_{2}{ }^{\prime}$ の差が大きいほど， $f_{2}$ は新第三 紀層地盤の上面で固定とした表層地盤の $1 / 4$ 波長則 による固有振動数と一致しない度合いが強いこと, 即ち $f_{2}$ のピークは新第三紀層地盤以深の地盤の弾 性の影響を受けて生じていることを示している.

図ー7に微動H/Vスペクトルから推定した地盤構造 を示した。新第三紀層深さは $100 \mathrm{~m} \sim 400 \mathrm{~m}$ 程度，地 震基盤深さは深いところで $1,500 \mathrm{~m}$ 程度とそれぞれ得 られており，地震基盤の春江と菅谷を除き大まかな 傾向はアレイ観測結果と一致している. 差の大きい これら2地点についてはあらためて地盤構造を照査 するなどその原因を究明する必要がある。なお，ア レイ観測の菅谷と山室の洪積層, 新第三紀層および 地震基盤の深さは文献(1)の観測值を再解析して定 めた改定值を用いていることを付記しておきたい.

\section{3. 重力探査}

\section{(1) 観測の概要}

観測は2008年10月24日〜26日に実施し，南北の 測線の観測点は図-1のNo.1〜 No.40の微動観測点の 測線に沿うように40地点とした。ささらに, 既存の重 力探査4) でデータの少ない丸岡付近と基盤が急峻な 東西の山際を含む山間部の45地点の計85点で実施し た。困ー8に観測点（青丸）をプロットしたものを示 した.

重力計は，ラコスト・ロンバーグ重力計(G-1034) を使用し，観測点の位置決定には，ディファレンシ ヤルGPS(Thales社 mobile mapper)を使用した。解析 で用いた重力データとして, 日本重力異常グリッド データベース $(\mathrm{CD}-\mathrm{ROM})^{13)}$ ， Gravity Database of

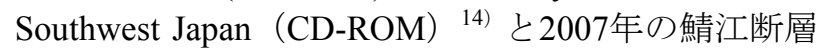
近辺で実施された観測点70点 ${ }^{15)}$ に, 今回測定した 85 点を加えた。

\section{（2）解析の概要}

観測により得られたブーゲ異常值をもとに丸岡周 辺と菅谷・山室周辺の基盤が露頭していると考えら れる地点でCVUR法 ${ }^{16)}$ を用いて密度推定を行った。 その結果，平野周辺の基盤の密度が $2.4 \mathrm{~g} / \mathrm{cm}^{3}$ ある と推定できた。そこで仮定密度を $2.4 \mathrm{~g} / \mathrm{cm}^{3}$ としたブ 一ゲ異常図（図-8）を作成して，2次元定量（2層モ デル）解析および2次元多層モデル解析を行った. 


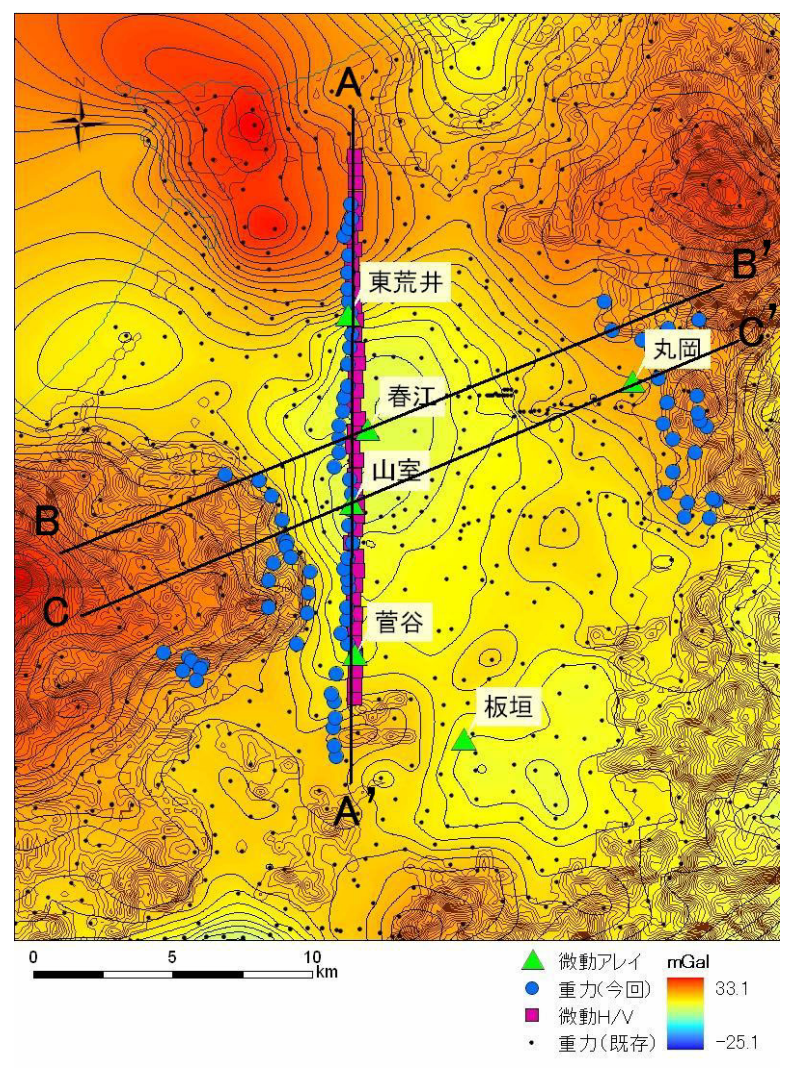

図-8 重力観測の測点位置とブーゲ異常図 （仮定密度 $2.4 \mathrm{~g} / \mathrm{cm}^{3}$ ，コンター間隔 $1.0 \mathrm{mGal}$ )

2次元定量解析では基盤と表層からなる均質な 2 層構造を仮定した。推定する断面には，観測を重点 的に行った南北方向の A-A'断面と, 両端で基盤が 露頭していると思われる福井平野を斜め東西方向に 通るB-B'断面とC-C'断面を設定した．図一8にその断 面位置を示す。ここに，表層の密度を $2.1 \mathrm{~g} / \mathrm{cm}^{3}$, 基 盤の密度を $2.4 \mathrm{~g} / \mathrm{cm}^{3}$ とした。また，拘束条件は次の ように与えた。即ち， B-B'断面とC-C'断面は両端に 基盤が露頭するように, A-A'断面ではB-B'断面とCC’断面の交点の深度を与えるとともに, 北端と南端 は基盤が露頭するように設定した.

2次元多層モデル解析は微動観測が行われた A-A' 断面で行った。ここでは，3層モデルを考え，1層目 を $1.8 \mathrm{~g} / \mathrm{cm}^{3} ， 2$ 層目を $2.1 \mathrm{~g} / \mathrm{cm}^{3} ， 3$ 層目を $2.4 \mathrm{~g} / \mathrm{cm}^{3}$ とし た. 1層目と2層目の境界は今回の微動 $\mathrm{H} / \mathrm{V}$ 探査の結 果を, 2層目と3層目の境界は2次元定量解析の結果 をそれぞれ基準にした。

ここで，密度の設定の考え方について説明してお きたい. 2次元定量解析では, 基盤と表層からなる 均質な2層の密度構造を仮定した。 その際，2層間の 密度差は $0.3 \mathrm{~g} / \mathrm{cm}^{3}$ とし, 表層 $2.1 \mathrm{~g} / \mathrm{cm}^{3}$, 基盤 $2.4 \mathrm{~g} / \mathrm{cm}^{3}$ の構造モデルとした。また，多層モデルでは，2層 モデルの表層をさらに $1.8 \mathrm{~g} / \mathrm{cm}^{3}$ と $2.1 \mathrm{~g} / \mathrm{cm}^{3}$ の層に分 けた。2章で述べた微動 H/Vによる解析結果では, 既往の微動探査の結果を参考に密度值を $1.7 \mathrm{~g} / \mathrm{cm}^{3}$,
表-1 各解析の構造モデルと地質との対応関係

\begin{tabular}{|c|c|c|c|c|c|c|}
\hline \multirow{3}{*}{ 地質 } & \multicolumn{2}{|c|}{ 微動H/Vモデル } & \multicolumn{4}{|c|}{ 重力モデル } \\
\hline & & & \multicolumn{2}{|c|}{ 2層 } & \multicolumn{2}{|c|}{ 3層 } \\
\hline & 層番号 & $\begin{array}{c}\text { Vsi } \\
(\mathrm{m} / \mathrm{s})\end{array}$ & 層番号 & $\begin{array}{c}\rho_{\mathrm{i}} \\
\left(\mathrm{g} / \mathrm{cm}^{3}\right)\end{array}$ & 層番号 & $\begin{array}{c}\rho_{\mathrm{i}} \\
\left(\mathrm{g} / \mathrm{cm}^{3}\right)\end{array}$ \\
\hline 沖積層 & (1) & 170 & \multirow{3}{*}{ (1) } & \multirow{3}{*}{2.1} & \multirow{2}{*}{ (1) } & \multirow{2}{*}{1.8} \\
\hline 洪積層 & (2) & 580 & & & & \\
\hline 新第三紀層 & (3) & 1,800 & & & (2) & 2.1 \\
\hline 地震基盤 & (4) & 3,200 & (2) & 2.4 & (3) & 2.4 \\
\hline
\end{tabular}

$1.8 \mathrm{~g} / \mathrm{cm}^{3}, \quad 2.0 \mathrm{~g} / \mathrm{cm}^{3}, \quad 2.5 \mathrm{~g} / \mathrm{cm}^{3}$ としたモデルを示して いる.ただし, 微動による構造の推定ではS波速度 が最も感度がよく, 密度值の変化に関しては構造モ デルに大きく影響しないため, 妥当な值とは限らな い.よって，ここでは微動で設定した構造モデルの 密度值とは㛜密に対応させずに, 既往の重力異常を 用いた解析結果 ${ }^{4)}$ や地質など, 現実の地盤構造を説 明できるモデルを考えた。微動の解析によるモデル および地質との対応関係について整理すると表-1の ようになる。ここに， $\rho_{i}$ は層の地盤密度である。

\section{（3）2次元定量解析結果}

2次元定量解析により得られた2層モデルの結果を 図-9に示す. A-A'断面では距離 $10 \mathrm{~km}$ の春江付近に おいて基盤の急な盛り上がりがみられる。 また，基 盤の最深部は東荒井と春江の間にみられ, 深度は $1,700 \mathrm{~m}$ に達している. 山室付近でも基盤が深くなっ ている. B-B'断面では基盤の最深部が $1,000 \mathrm{~m}$ と浅く, C-C’断面では基盤の最深部が $1,600 \mathrm{~m}$ に達している.

\section{（4）2次元多層モデル解析結果}

図-10に3層モデルを示した。この図より，低密度 の層を1層入れたことにより，2層目と3層目の深さ が，2層モデルの境界に比べ全体的に浅くなってい ることがわかる.また, 図-11には重力, 微動アレ イおよび微動H/Vによる地下構造モデルを比較して 示した。同図(a)の新第三紀層境界と1層目と2層目 の境界についてみると, 北側( $\mathrm{A}$ 側)は3者とも類似し た傾向を示すものの南半分 (A'側) は互いに大きな差 を示す. 同図(b)の地震基盤面と 2 層目と 3 層目の境 界についてみると, 重力, 微動アレイおよび微動 H/Vによる結果は, 微動H/Vの南北両端とアレイの 菅谷と春江を除き概放一致しているといえる.

差の大きい地点については, 基盤あるいは表層 の密度分布が断層などによって均質ではない（層構 造になっていない）ことも考えられるため，この周 辺の地質環境等を再度吟味して今後検討する必要が ある。 


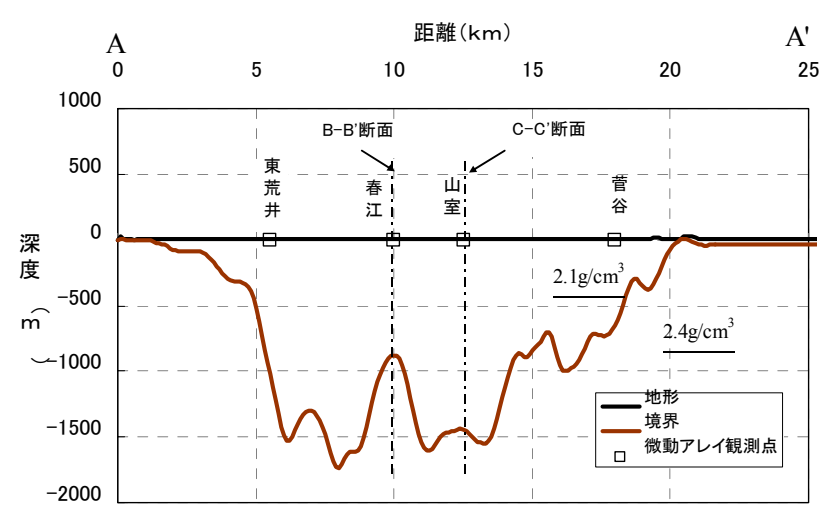

(a) A-A 断面

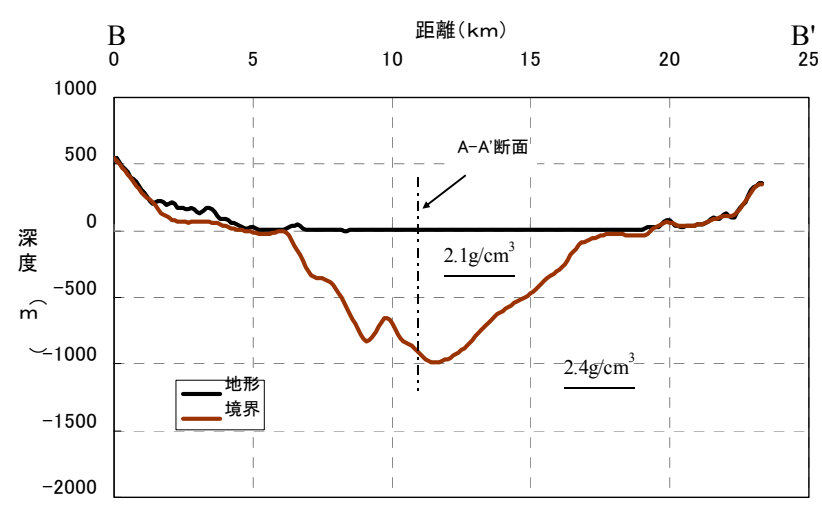

(b) B-B' 断面

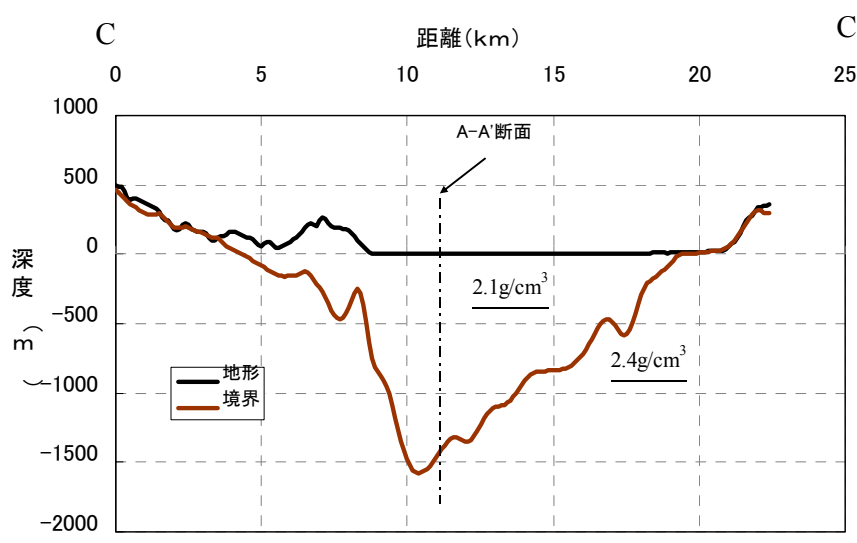

(c) C-C’ 断面

図-9 重力異常から推定した2次元 2 層モデル

\section{4. おわりに}

（1）既往の4つのアレイ観測点を通る福井平野の西

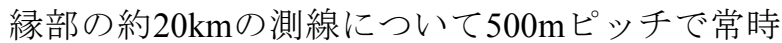
微動観測と重力観測を，東西の山地において重力 観測を行った。

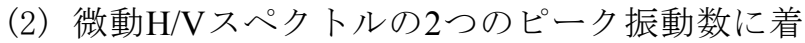
目した簡易な地盤構造推定法を提案して地震基盤 を含む地盤構造の推定を試みた。その結果，新 第三紀層深さは $100 \mathrm{~m} \sim 400 \mathrm{~m}$ 程度, 地震基盤深さ は深いところで1,500mとそれぞれ得られた。

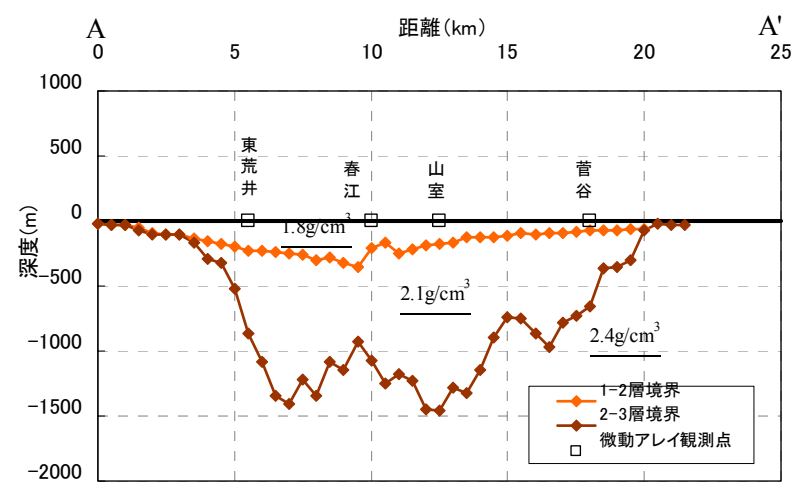

図-10 重力異常から推定した2次元多層モデル

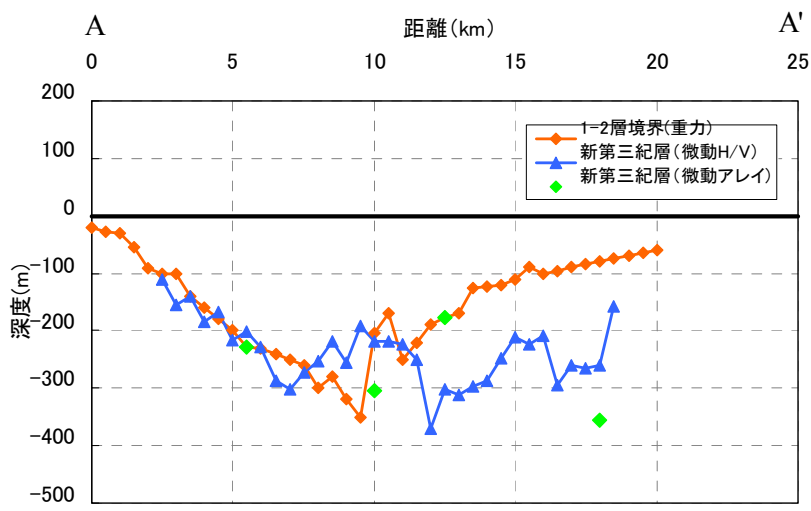

(a) 1-2層境界

$\mathrm{C}^{\prime}$

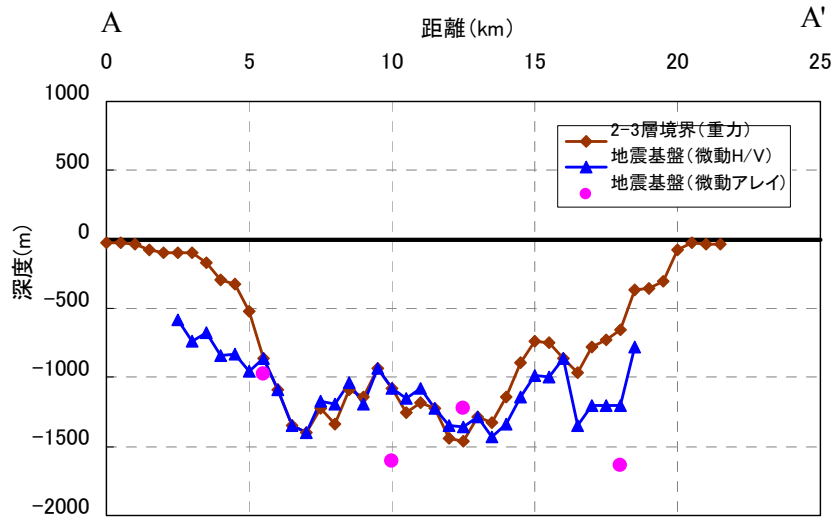

(b) 2-3層境界

図-11 地下構造モデルの比較

（3）重力データをもとに福井平野の2次元の密度構 造を推定した。その結果, 新第三紀層深さは深い ところで $350 \mathrm{~m}$ 程度で, 地震基盤の深さは最大 $1,500 \mathrm{~m}$ 程度であると推察された。

（4）重力解析, 微動アレイおよび微動 H/Vから推定 した新第三紀層の深さについて比較した結果, 測 線の北側においてアレイ観測の結果に概ね一致し た. また地震基盤の深さについては, 微動H/Vの 南北両端とアレイの菅谷と春江を除き概ね一致し た. 差の大きい地点については, 今後検討する必 要がある。 
謝辞：本研究を実施するにあたり卒業研究生の福井 工業大学の伊原和紀氏と相馬友氏, 鳥取大学の杉浦 慎一氏の協力を得た。ここに記して謝意を表します。

\section{参考文献}

1) 安井譲, 野口竜也 : 微動アレイ観測に基づく福井平野 の深部地盤速度構造の照査・検討, 福井地震 60 周年- $\mathrm{I}$, 月刊地球 2008 年 11 月号, 通巻 350 号, Vol.30, No.9, pp.444-452,2008.

2) 時松孝次, 宮寺泰生 : 短周期微動に含まれるレイリー 波の特性と地盤構造の関係, 日本建築学会構造系論文 集, 第439号, pp.81-87,1992年2月.

3) 若松邦夫, 野畑有秀: 福井平野の地下構造と 1948年福 井地震の被害 一その 1 微動 $\mathrm{H} / \mathrm{V}$ の特性と推定地下構 造一, 日本建築学会大会学術講演概要集（九州）, pp.227-228,1998.

4) 小林直城, 平松良浩, 河野芳輝, 竹内文明 : 重力異常 による福井平野の3次元基盤構造の推定一福井地震拉よ びその周辺の活断層との関係, 地震, 第 2 輯, 第 54 巻,pp.1-8,2001.

5) 山中浩明, 栗田勝実, 瀬尾和大, 小嶋啓介, 佐藤浩明, 宮腰研, 赤澤隆士 : 微動アレイ観測による福井平野の $\mathrm{S}$ 波速度構造の推定，地震,第2輯,第53巻,pp.37-43,2000.

6) 狐崎長琅, 後藤典俊, 小林芳正, 井川猛, 堀家正則, 斎藤徳美, 黒田徹, 山根一修, 奥住宏一: 地震動予測 のための深層地盤P・S波速度の推定, 自然災害科学, 9(3),pp.1-17,1990.

7) 久田嘉章 : 成層地盤における正規モード解及びグリー ン関数の効率的な計算法, 日本建築学会構造系論文集,
第501号, pp.49-56,1997年11月.

8) 石田良平, 村瀬治比古, 小山修平 : パソコンで学ぶ遺 伝的アルゴリズムの基礎と応用，森北出版，1997.

9) 山中浩明, 石田寛 : 遺伝的アルゴリズムによる位相速 度の逆解析, 日本建築学会構造系論文集, 第468号, pp.9-17,1997年2月.

10) Arai, H. and Tokimatsu, K. : S-Wave Velocity Profiling by Inversion of Microtremor H/V Spectrum, Bull. Seism. Soc. Am., Vol.94, No.1, pp.53-63, Feb. 2004.

11) 上林広敏 : 堆積盆地基盤面形状推定のための長周期微 動水平／上下スペクトルの逆解析, 日本建築学会構造 系論文集，第603号，pp.69-76,2006年5月.

12) 小嶋啓介：強震および常時微動観測に基づく福井平野 の地下構造の推定, 福井地震60周年- I , 月刊地球 2008 年11月号, 通巻350号, Vol.30, No.9, pp.453-460,2008.

13) 駒澤正夫 : 日本重力異常グリッドデータベース, 日本 重力 CD-ROM第2版, 数值地質図 P-2, 地質調査総合セン ター, 2002.

14) The Gravity Research Group in Southwest Japan : Gravity Measurements and Database in Southwest Japan, Gravity Database of Southwest Japan (CD-ROM), Bull. Nagoya University Museum, Special Rept., No.9, 2002.

15) 野口竜也, 小嶋啓介, 大畑至 : 重力異常による鯖江断 層周辺の基盤構造推定, 第7回アジア国際地震学会連合 (ASC) 総会・2008年日本地震学会秋季大会合同大会概 要集, Y1-206, 2008.

16) Komazawa, M. : Gravimetric Analysis of Volcano and its Interpretation, J. Geod. Soc. Japan, Vol.41-1, pp.1745, 1995.

\title{
SURVEY ON UNDERGROUND SOIL STRUCTURE OF THE FUKUI PLAIN THROUGH MICROTREMOR AND GRAVITY OBSERVATIONS
}

\author{
Yuzuru YASUI, Tatsuya NOGUCHI, Yuhichi HASHIMOTO, Eiji NAKAYA \\ and \\ Takao KAGAWA
}

\begin{abstract}
A dense microtremor $\mathrm{H} / \mathrm{V}$ and gravity observation were done on the line from the north to the south on the west part of the Fukui Plain in order to obtain two dimensional underground soil structures for interpolating four site data surveyed previously by microtremor array observation. The gravity observation was done also in the mountainous districts in the east and west areas where bedrock was outcrop. A simple method being able to deduce the soil structure from the surface to the depth of seismic bedrock by simulating two kinds of peak frequencies of the microtremor $\mathrm{H} / \mathrm{V}$ spectra with those of the Rayleigh wave fundamental amplitude mode ratio spectra was proposed. It was confirmed that the two dimensional underground soil structures obtained through the $\mathrm{H} / \mathrm{V}$ and gravity surveys interpolated roughly the array observation results.
\end{abstract}

